\title{
Kinetika Reaksi Penurunan Kafein dan Asam Klorogenat Biji Kopi Robusta melalui Pengukusan Sistem Tertutup
}

\author{
Kinetics Reaction of Caffeine and Chlorogenic Acids Reduction of Robusta Coffee Beans by Steaming in \\ Closed Systems
}

\author{
Sapto Kuncoro' ${ }^{1 *}$, Lilik Sutiarso², Joko Nugroho², Rudiati Evi Masithoh² \\ ${ }^{1}$ Jurusan Teknik Pertanian, Fakultas Pertanian, Universitas Lampung, Jl. Prof. Sumantri Brojonegoro No. 1, Bandar \\ Lampung 35145, Indonesia \\ 2Departemen Teknik Pertanian dan Biosistem, Fakultas Teknologi Pertanian, Universitas Gadjah Mada, Jl, Flora No. \\ 1, Bulaksumur, Yogyakarta 55281, Indonesia \\ *Email: sapto.kuncoro@fp.unila.ac.id
}

Submisi: 12 Juli 2017; Penerimaan: 27 November 2017

\begin{abstract}
ABSTRAK
Penelitian ini bertujuan untuk mengkaji hubungan antara suhu dan lama pengukusan terhadap penurunan kandungan kafein dan asam klorogenat serta menentukan energi aktivasi (Ea) dengan pendekatan persamaan Arrhenius. Biji kopi Robusta masing-masing seberat $750 \mathrm{~g}$ dikukus dalam autoklaf (sistem tertutup) pada suhu 100, 110, dan $120^{\circ} \mathrm{C}$ masing-masing selama $1,2,3,4,5$, 6, dan 7 jam. Penelitian dilakukan dengan 3 kali ulangan. Analisis kafein dan asam klorogenat dilakukan menggunakan HPLC. Pengukusan biji kopi pada suhu 100, 110, dan $120^{\circ} \mathrm{C}$, menghasilkan penurunan kandungan kafein dan asam klorogenat tertinggi pada pengukusan selama 7 jam. Penurunan kandungan kafein selama 7 jam pada suhu pengukusan 100,110 , dan $120^{\circ} \mathrm{C}$ berturut-turut $13 \%, 18 \%$, dan $25 \%$. Kandungan asam klorogenat mengalami penurunan $37 \%, 50 \%$, dan $59 \%$ berturut-turut pada suhu 100 , 110 , dan $120^{\circ} \mathrm{C}$. Pada semua suhu yang diuji, penurunan kafein dan asam klorogenat mengikuti reaksi orde satu. Penurunan kafein mengikuti persamaan $y=-0,019 x+0,862, y=-0,023 x+0,820$, dan $y=-0,033 x+0,759$, sedangkan untuk asam klorogenat mengikuti persamaan $y=-0,071 x+1,421, y=-0,089 x+1,271$, dan $y=-$ $0,120 x+1,201$. Besarnya energi aktivasi penurunan kafein dan asam klorogenat berturut turut adalah $33.543,66$ $\mathrm{kJ} / \mathrm{molK}$ dan 31.934,91 kJ/Mok.
\end{abstract}

Kata kunci: Energi aktivasi; kafein; asam klorogenat

\begin{abstract}
This study was aimed to examine the correlation between temperature and duration of steaming on caffeine and chlorogenic acid reduction as well as to determine energy activation (Ea) according to Arrhenius equation. About $750 \mathrm{~g}$ of Robusta coffee was steamed by autoclaving at $100,110,120^{\circ} \mathrm{C}$ for $1,2,3,4,5,6$ and 7 hours. The study was conducted in 3 replications. Analyses of caffeine and chlorogenic acid were performed using HPLC. Steaming coffee beans at 100,110 and $120^{\circ} \mathrm{C}$ resulted in the highest decrease of caffeine and chlorogenic acids content for 7 hours by $13 \%, 18 \%$ and $25 \%$ for caffeine; and by $37 \%, 50 \%$ and $59 \%$ for chlorogenic acids. At all temperatures investigated, decaffeination and chlorogenic acid reduction followed first order reaction. The decaffeination equation at $100^{\circ} \mathrm{C}, 110^{\circ} \mathrm{C}$ and $120^{\circ} \mathrm{C}$ followed equation of $\mathrm{y}=-0.019 \mathrm{x}+0.862, \mathrm{y}=-0.023 \mathrm{x}+0.820$, and $\mathrm{y}=-0.033 \mathrm{x}+$ 0.759 , respectively. Meanwhile, the chlorogenic acid reduction at $100^{\circ} \mathrm{C}, 110^{\circ} \mathrm{C}$, and $120^{\circ} \mathrm{C}$ followed equation of $\mathrm{y}$ $=-0.071 \mathrm{x}+1.421, \mathrm{y}=-0.089 \mathrm{x}+1.271$, and $\mathrm{y}=-0.120 \mathrm{x}+1.201$. Activation energies of decaffeination and chlorogenic acid reduction were $33,543.66 \mathrm{~kJ} / \mathrm{mol} \mathrm{K}$ and $31,934.91 \mathrm{~kJ} / \mathrm{mol} \mathrm{K}$, respectively.
\end{abstract}

Keywords: Activation energy; caffeine; chlorogenic acids

\section{PENDAHULUAN}

Kopi merupakan salah satu minuman yang paling banyak dikonsumsi di seluruh dunia (Lara, 2010), termasuk juga di Indonesia. Minuman kopi disukai konsumen bukan sebagai sumber nutrisi melainkan sebagai minuman penyegar karena memiliki cita rasa dan aroma yang khas. Cita rasa ini disebabkan 
kandungan senyawa kimia yang kompleks diantaranya yang dominan adalah senyawa kafein dan asam klorogenat.

Di Indonesia dikenal dua jenis kopi yaitu kopi Robusta (Coffea canephora) dan kopi Arabika (Coffea arabica). Kopi jenis Robusta mengandung kafein lebih tinggi yaitu $1,6-2,4 \%$ yang jumlahnya hampir dua kali lipat bila dibandingkan dengan kopi Arabika yang hanya mengandung 0,9-1,2\%.(Clarke \& Macrae, 1987). Kandungan asam klorogenat pada kopi Robusta sekitar 7,0-10,0 \% (Clifford \& Jarvis, 1988). Peranan utama kafein di dalam tubuh adalah meningkatkan kerja psikomotor sehingga tubuh tetap terjaga dan memberikan efek fisiologis berupa peningkatan energi. Manfaat kafein tersebut menjadi tidak berlaku bagi penderita penyakit jantung, diabetes, maag, dan hipertensi karena kafein justru dapat memicu penyumbatan pembuluh darah (Sivetz \& Desroiser, 1979). Kafein juga dapat menyebabkan peningkatan tekanan darah sehingga dapat membahayakan penderita jantung dan tekanan darah tinggi (Lelyana, 2008). Meskipun masih ada kontroversi mengenai manfaat ataupun risiko mengkonsumsi kopi, hasil penelitian khusus epidemiologi dan meta-analisis, konsumsi kopi tidak menyebabkan risiko kematian (Tamakoshi dkk., 2011). Oleh sebab itu bagi penikmat kopi yang mengidap penyakit tersebut perlu disediakan kopi dengan kandungan kafein yang sedang atau medium yaitu sekitar setengahnya dari kandungan kafein awal.

Asam klorogenat merupakan antioksidan yang berguna untuk mengurangi efek kerusakan sel akibat radikal bebas dan pendorong metabolisme yang meminimalkan pelepasan glukosa berlebihan dari hati ke dalam darah. Beberapa penelitian terbaru telah melaporkan asam klorogenat dapat meningkatkan kesehatan retina. Meskipun data terbatas, penelitian menunjukkan bahwa CGA mungkin memiliki potensi efek kesehatan termasuk kemampuan untuk mengurangi risiko penyakit kardiovaskuler (Mubarak dkk., 2012), mengurangi risiko diabetes tipe dua (Van Dijk dkk., 2009), dan perbaikan dalam fungsi kognitif (Cropley dkk., 2012). Penelitian lain menunjukkan bahwa asam klorogenat menghambat pelepasan glukosa ke dalam aliran darah yang dapat menurunkan tekanan darah dan tidak ada efek samping negatif (Panggabean, 2011). Oleh sebab asam klorogenat merupakan senyawa yang penting bagi kesehatan maka sedapat mungkin harus dipertahankan (diminimalisir penurunannya) selama proses pengolahan biji kopi termasuk proses penurunan kafein (dekafeinasi) maupun proses penyangraian.

Proses dekafeinasi umumnya menggunakan pelarut kimia seperti metilen klorida, atau etil asetat. Bahanbahan kimia ini akan tertinggal di dalam biji kopi dekaf yang dikonsumsi yang dapat mengganggu kesehatan. Kopi yang dihasilkan dari proses dekafeinasi disebut kopi dekaf yang hanya memiliki kandungan kafein antara 0,1-0,3\% (Widyotomo, S., Purwadaria, H.K., \& Ismayadi, 2012). Dalam penelitian kali ini penurunan kafein hanya menggunakan air sebagai pelarut yang paling sederhana dan mudah diperoleh. Selain murah, efek samping air terhadap kesehatan dan lingkungan pun sangat kecil. Kemampuan air melarutkan kafein dari dalam biji kopi sangat terbatas jika prosesnya dilakukan pada suhu rendah. Sehingga penelitianpenelitian terdahulu selalu mengkombinasikannya dengan pelarut kimia seperti etil asetat; (Almada, 2009; Wijaya \& Yuwono, 2015), limbah cair fermentasi biji kakao dan asam asetat (Widyotomo, 2012). Dalam penelitian ini, penurunan kafein biji kopi dilakukan dengan pengukusan dalam sistem tertutup pada suhu tinggi yaitu $100-120^{\circ} \mathrm{C}$ dan lama pengukusan 1 sampai 7 jam tanpa pelarut kimia. Penelitian ini bertujuan untuk mengkaji hubungan antara suhu dan lama pengukusan terhadap penurunan kandungan kafein dan asam klorogenat biji kopi tanpa penyangraian serta menentukan energi aktivasi (Ea) dengan pendekatan persamaan kinetika reaksi dan persamaan Arrhenius. Model kinetika sudah banyak digunakan untuk proses pengolahan pangan dan hasil pertanian. Namun untuk kinetika perubahan kandungan kafein dan asam klorogenat pada biji kopi hasil pengukusan, terutama pada sistem tertutup belum pernah dilakukan.

\section{METODE PENELITIAN}

\section{Bahan dan Alat}

Biji kopi yang digunakan dalam penelitian ini yaitu kopi jenis Robusta yang berasal dari Sumberjaya, Kabupaten Lampung Barat, dengan kualitas mutu 1 dan kadar air sekitar 13-14\% (bb). Alat yang digunakan untuk mengukus kopi adalah autoklaf (LabTech model LAC-5040S). Alat ini sebagai tempat pengukusan (steaming) biji kopi sistem tertutup. Autoklaf ini berdiameter tabung $35 \mathrm{~cm}$ dan tinggi tabung 44,7 cm dilengkapi dengan sebuah chamber (sarangan).

\section{Preparasi Biji Kopi}

Biji kopi masing-masing seberat $0,75 \mathrm{~kg}$ dikukus dalam autoklaf dengan variasi suhu kukus $100{ }^{\circ} \mathrm{C}, 110$ ${ }^{\circ} \mathrm{C}, 120{ }^{\circ} \mathrm{C}$ masing-masing selama $1,2,3,4,5,6$, dan 7 jam. Sebelum dioperasikan, autoklaf diisi air dingin sebanyak 4 L. Kemudian chamber yang sudah berisi 0,75 kg kopi yang akan dikukus dimasukkan ke dalam autoklaf, lalu autoklaf ditutup rapat dengan mengencangkan baut pengaman agar tidak ada uap yang keluar dari bibir (seal) autoklaf. Suhu pengukusan disetel sesuai dengan suhu yang dinginkan selama 1 jam. Bila ingin menambah 1 jam lagi tinggal mereset kembali waktu tambahan 1 jam, begitu seterusnya tergantung lama waktu yang ditentukan.

\section{Analisis Kopi Kukus}

Biji kopi hasil pengukusan dijemur hingga mencapai kadar air sekitar $12-14 \%$. Selanjutnya digiling dengan ukuran 40 mesh tanpa melalui proses penyangraian terlebih dahulu. Kopi bubuk dibagi menjadi 2 bagian, bagian pertama untuk analisis kafein dan bagian kedua untuk analisis asam klorogenat. Analisis kafein dan 
asam klorogenat dilakukan di UPT Laboratorium Terpadu dan Sentra Inovasi Teknologi di Universitas Lampung dengan HPLC (High Pressure Liquid Chromatografi). Jenis HPLC yang digunakan adalah Shimadzu tipe Prominance LC-20AD. Prosedur analisis kafein mengacu pada standar SNI 01-3542-2004 A2 Cara II (BSN, 2004), sedangkan prosedur analisis asam klorogenat mengacu pada Standar Jurnal Scholars Reserach Library (Tripathi, Koshy, Kachroo, \& Mayachari, 2014).

\section{Analisis Data}

Perubahan kandungan kafein dan asam klorogenat didekati dengan persamaan kinetika reaksi. Sedangkan untuk mengetahui pengaruh suhu terhadap reaksi didekati dengan persamaan Arrhenius.

Laju perubahan kandungan kafein dan asam klorogenat dapat dijelaskan dengan Persamaan 1.

$\frac{\mathrm{dM}}{\mathrm{dt}}= \pm \mathrm{k}[\mathrm{M}]^{\mathrm{n}}$

dengan $\mathrm{M}=$ konsentrasi kafein atau asam klorogenat pada waktu $\mathrm{t}$, $\mathrm{k}=$ konstanta laju reaksi, dan $\mathrm{n}=$ orde reaksi.

Untuk $\mathrm{n}=0$ (orde nol), menjadi Persamaan 2.

$$
\begin{aligned}
& \frac{\mathrm{dM}}{\mathrm{dt}}= \pm \mathrm{k} \mathrm{M}^{0} \\
& \frac{\mathrm{dM}}{\mathrm{dt}}= \pm \mathrm{k} \\
& \int d M= \pm \mathrm{k} \int d t \\
& M t-M_{0}= \pm \mathrm{kt} \\
& M t=M_{0} \pm \mathrm{kt}
\end{aligned}
$$

Untuk n = 1 (orde satu), menjadi Persamaan 3.

$$
\begin{aligned}
& \frac{d M}{d t}= \pm k^{1} \\
& \int \frac{d M}{d t}=\int \pm k d t \\
& \ln [M]_{0}^{t}= \pm k t \\
& \ln \frac{M t}{M 0}= \pm k t \\
& \frac{M t}{M 0}=e^{ \pm k t} \\
& M t=M_{0} e^{ \pm k t}
\end{aligned}
$$

Konstanta laju reaksi $(\mathrm{k})$ tergantung pada suhu reaktan. Kondisi ini dapat dijelaskan dalam persamaan Arrhenius (4)

$$
\begin{aligned}
& \mathrm{k}_{0}=\mathrm{A}_{0} \cdot \mathrm{e} \frac{-\mathrm{EA}}{\mathrm{R} \mathrm{To}_{0}} \\
& \mathrm{k}=\mathrm{A}_{0} \cdot \mathrm{e} \frac{-E A}{R T}
\end{aligned}
$$

Dari Persamaan 4 disubstitusi menjadi Persamaan 5.

$\frac{\mathrm{k}}{\mathrm{ko}}=\mathrm{e} \frac{-\mathrm{EA}}{\mathrm{R}}\left[\frac{1}{\mathrm{~T}} \frac{1}{\mathrm{To}}\right]$

$k=k_{0} \cdot e \frac{-E A}{R T}$

$\mathrm{k}=\mathrm{k}_{0} \cdot \mathrm{e} \frac{\mathrm{Ea}}{\mathrm{R}}\left(\frac{1}{\mathrm{~T}}\right)$

Besarnya energi aktivasi (Ea) ditetapkan berdasarkan Persamaan 6.

$\ln \mathrm{k}=\ln \mathrm{k}_{0}-\frac{E a}{R}\left(\frac{1}{T}\right)$

dengan $\mathrm{k}=$ konstanta laju reaksi, $\mathrm{k}_{0}=$ faktor frekuensi reaksi, $\mathrm{R}=$ konstanta gas (besarnya $8,314 \mathrm{~kJ} / \mathrm{molK}$ ), $\mathrm{Ea}=$ energi aktivasi, dan $\mathrm{T}=$ suhu mutlak $(\mathrm{K})$.

\section{HASIL DAN PEMBAHASAN}

\section{Kandungan Kafein Biji Kopi Hasil Pengukusan}

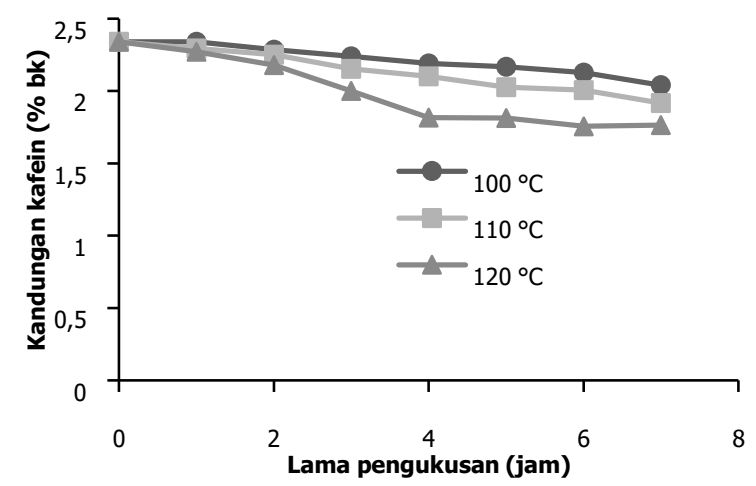

Gambar 1. Penurunan kandungan kafein biji kopi selama pengukusan

Dari Gambar 1 terlihat bahwa semakin tinggi suhu pengukusan dan semakin lama biji kopi dikukus menunjukkan adanya kecenderungan penurunan kandungan kafein pada biji kopi walaupun nilainya kecil. Setelah pengukusan selama 7 jam, berturutturut pada suhu 100,110 , dan $120{ }^{\circ} \mathrm{C}$ kandungan kafein turun menjadi 2,04\%, 1,92\%, dan 1,76\% dari kandungan awal (kontrol) 2,34\%. Artinya masingmasing suhu telah menurunkan kandungan kafein $13 \%$, 18\%, dan 25\%. (Sivetz, M. \& Desroiser, 1979) menyatakan bahwa perlakuan panas dapat memecah ikatan senyawa kompleks kafein, sehingga senyawa kafein menjadi bebas dengan ukuran yang lebih kecil dan mudah bergerak. Namun penurunan kafein masih rendah yang berarti kandungan kafein pada biji kopi masih tinggi. Tingginya kandungan kafein ini disebabkan uap panas dalam autoklaf terperangkap dalam sistem tertutup walaupun kadar air dan volume biji kopi meningkat. Hal ini mengakibatkan uap panas menjadi jenuh dan tidak mampu menarik sebagian besar senyawa kafein keluar dari biji kopi. 
Tabel 1. Persamaan regresi linier orde nol dan orde satu kandungan kafein

\begin{tabular}{|c|c|c|c|c|}
\hline \multirow{2}{*}{ Suhu $\left({ }^{\circ} \mathrm{C}\right)$} & \multicolumn{2}{|c|}{ Persamaan regresi linier } & \multicolumn{2}{|c|}{$\mathrm{R}^{2}$} \\
\hline & Orde nol & Orde satu & Orde nol & Orde satu \\
\hline 100 & $y=-0,042 x+2,365$ & $y=-0,019 x+0,862$ & 0,971 & 0,966 \\
\hline 110 & $y=-0,048 x+2,268$ & $y=-0,023 x+0,820$ & 0,891 & 0,902 \\
\hline 120 & $y=-0,066 x+2,142$ & $y=-0,033 x+0,759$ & 0,656 & 0,674 \\
\hline
\end{tabular}

Dari Tabel 1 diketahui bahwa perubahan kafein biji kopi kukus mengikuti reaksi orde satu dengan nilai $\mathrm{R}^{2}$ mendekati 1 kecuali pada suhu $100{ }^{\circ} \mathrm{C}$ mengikuti orde nol.

Besarnya nilai $\mathrm{k}$ tiap suhu dapat dilihat pada Tabel 2. Semakin tinggi suhu maka semakin tinggi nilai $\mathrm{k}$. Hal yang sama diperoleh dari hasil penelitian (Renate, Pratama, Yuliati, \& Priyanto, 2014) yang meneliti penurunan capsaicin diperoleh harga k pada suhu $30{ }^{\circ} \mathrm{C}$ sebesar 0,012 lebih tinggi dari pada suhu $20^{\circ} \mathrm{C}$ sebesar 0,092 . Secara kimia fisik, pada suhu yang lebih tinggi, panas dan tekanan yang dihasilkan juga meningkat sehingga laju penurunan kafein semakin besar.

Tabel 2. Parameter Arrhenius perubahan kandungan kafein

\begin{tabular}{cccc}
\hline \multicolumn{2}{c}{ Suhu $\left({ }^{\circ} \mathrm{K}\right)$} & \multicolumn{2}{c}{ Persamaan matematis } \\
\hline $\mathrm{T}$ & $1 / \mathrm{T}$ & $\mathrm{k}$ & $\ln \mathrm{k}$ \\
\hline 373 & 0,002681 & 0,019 & $-3,96332$ \\
383 & 0,002611 & 0,023 & $-3,77226$ \\
393 & 0,002545 & 0,033 & $-3,41125$ \\
\hline
\end{tabular}

Nilai energi aktivasi (Ea) perubahan kafein biji kopi kukus diperoleh dengan memplotkan antara In $\mathrm{k}$ dan $1 / \mathrm{T}$ (1/K) seperti pada Gambar 2.

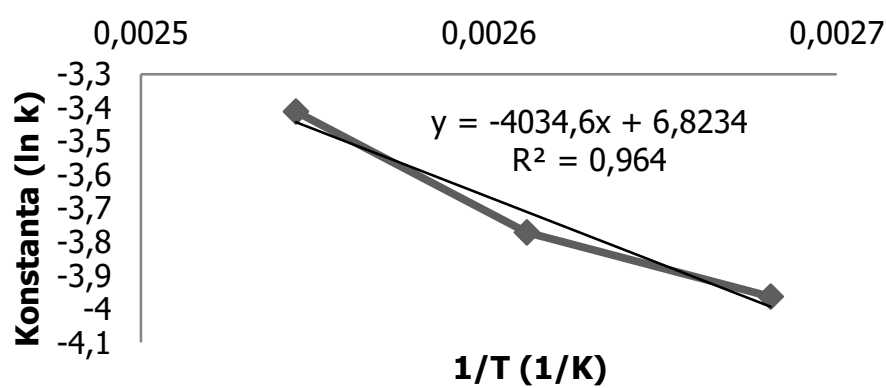

Gambar 2. Plot Arrhenius perubahan kandungan kafein

Hasil analisis regresi linier dari plot $1 / T$ dan In $k$ pada penurunan kafein (Gambar 2), diperoleh persamaan $\mathrm{y}=-4034,6 \mathrm{x}+6,823$; artinya nilai $\mathrm{Ea} / \mathrm{R}=$ $-4034,6$. Konstanta $R$ adalah nilai tetapan gas $=8,314$ $\mathrm{kJ} / \mathrm{molK}$, sehingga nilai energi aktivasi $(\mathrm{Ea})$ diketahui $=$ $4034,6 \times 8,314 \mathrm{~kJ} / \mathrm{molK}=33.543,66 \mathrm{~kJ} / \mathrm{molK}$. Nilai Ea tersebut adalah energi minimal yang dibutuhkan molekul dalam biji kopi untuk menurunkan kandungan kafein yaitu sebesar 33.543,66 kJ/molK.
Untuk menguji persamaan pada Tabel 1 (orde 1), perlu dilakukan validasi dengan menghitung kandungan kafein prediksi dengan rumus $\mathrm{y}=\exp (\mathrm{a} . \mathrm{t}+\mathrm{b})$ yang diperoleh dari Tabel 1. Hubungan kandungan kafein observasi dan prediksi untuk masing-masing suhu ditampilkan berturut-turut pada Gambar 3, 4, dan Gambar 5.

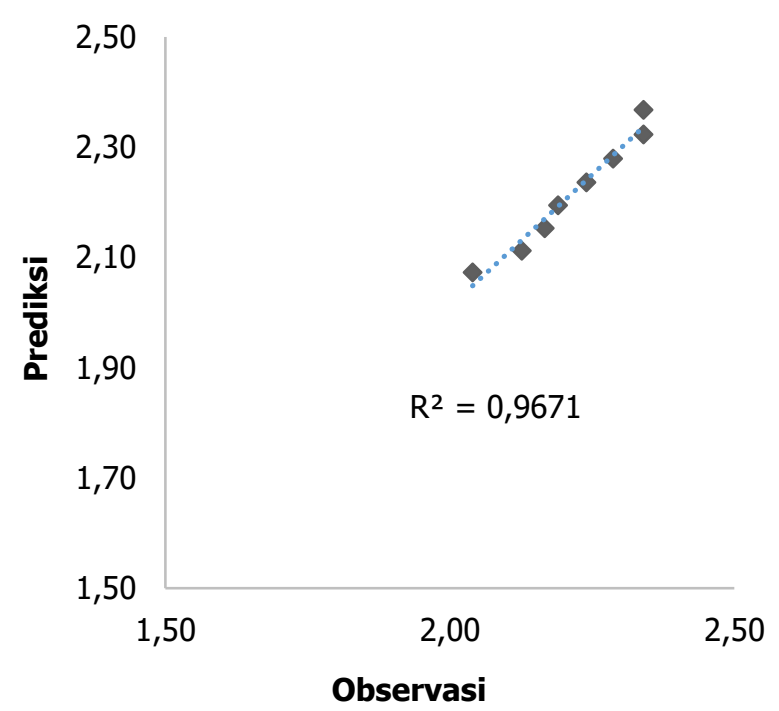

Gambar 3. Hubungan kandungan kafein (\%) prediksi dan observasi pada suhu $100^{\circ} \mathrm{C}$

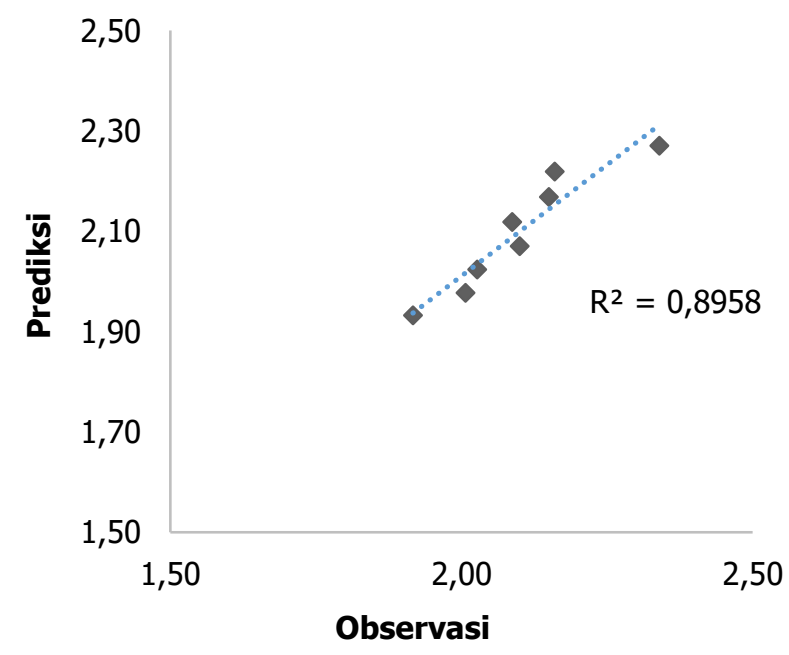

Gambar 4. Hubungan kandungan kafein (\%) prediksi dan observasi pada suhu $110^{\circ} \mathrm{C}$ 
Tabel 3. Persamaan regresi linier orde nol dan orde satu kandungan asam klorogenat

\begin{tabular}{|c|c|c|c|c|}
\hline \multirow{2}{*}{$\begin{array}{l}\text { Suhu } \\
\left({ }^{\circ} \mathrm{C}\right)\end{array}$} & \multicolumn{2}{|c|}{ Persamaan regresi linier } & \multicolumn{2}{|c|}{$\mathrm{R}^{2}$} \\
\hline & Orde nol & Orde satu & Orde nol & Orde satu \\
\hline 100 & $y=-0,231 x+4,081$ & $y=-0,071 x+1,421$ & 0,966 & 0,966 \\
\hline 110 & $y=-0,248 x+3,545$ & $y=-0,089 x+1,271$ & 0,853 & 0,917 \\
\hline 120 & $y=-0,293 x+3,315$ & $y=-0,120 x+1,201$ & 0,793 & 0,883 \\
\hline
\end{tabular}

Gambar 3 dan Gambar 4 menunjukkan nilai koefisien determinasi 0,967 pada suhu $100{ }^{\circ} \mathrm{C}$, dan 0,895 pada suhu $110{ }^{\circ} \mathrm{C}$. Besarnya nilai tersebut mendekati angka 1 atau hampir linier sehingga dapat dikatakan besarnya kandungan kafein prediksi mendekati nilai observasi. Pada suhu $120{ }^{\circ} \mathrm{C}$ (Gambar 5) nilai $R^{2}$-nya 0,677 , ini berarti nilai prediksi masih jauh dari nilai observasi. Hal ini karena penurunan kafein pada suhu $120{ }^{\circ} \mathrm{C}$ fluktuasinya lebih tajam yang cenderung tidak linier dibandingkan pada suhu 100 dan $110^{\circ} \mathrm{C}$ (Gambar 1).

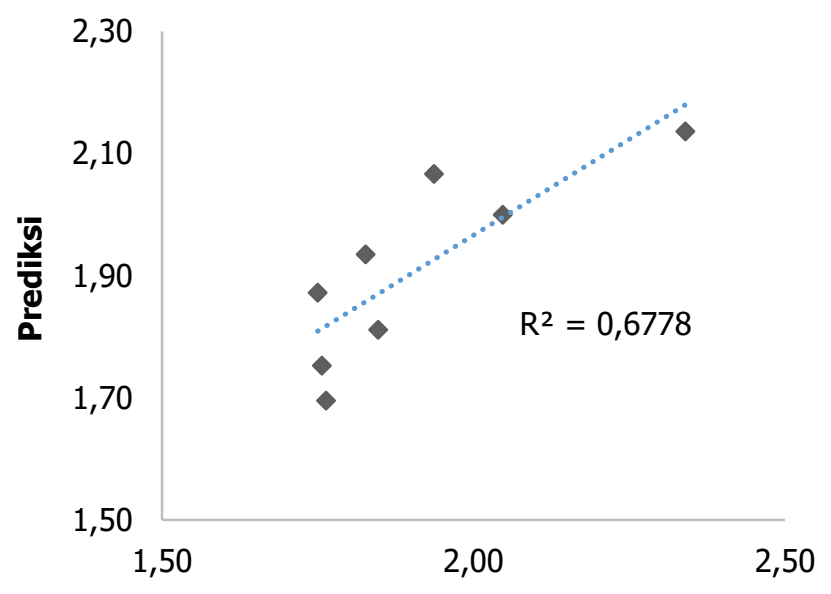

\section{Observasi}

Gambar 5. Hubungan kandungan kafein (\%) prediksi dan observasi pada suhu $120^{\circ} \mathrm{C}$

\section{Kandungan Asam Klorogenat Biji Kopi Hasil Pengukusan}

Dari Gambar 6 terlihat bahwa kandungan asam klorogenat mengalami penurunan dengan semakin lama dan semakin tinggi suhu pengukusan. Jika dibandingkan dengan kafein, kurva penurunan asam klorogenat lebih curam pada setiap suhu dan lama pengukusan. Setelah kopi dikukus selama 7 jam, berturut-turut pada suhu 100 , 110, dan $120^{\circ} \mathrm{C}$, kandungan asam klorogenat menjadi $2,53 \%, 2,00 \%$, dan $1,63 \%$ dari kandungan semula (kontrol) 4,01\%, atau masing-masing suhu menurunkan kandungan asam klorogenat $37 \%, 50 \%$, dan $59 \%$. Hal ini sesuai dengan pernyataan (Clifford, 1985) bahwa senyawa asam klorogenat lebih rentan terhadap suhu tinggi karena sifatnya yang mudah terhidrolisis menjadi senyawa yang mudah larut dalam air dan keluar dari biji kopi melalui uap panas. Penurunan asam klorogenat ini masih menguntungkan karena masih dapat mempertahankan sekitar setengah kandungan asam klorogenat yang berfungsi sebagai antioksidan.

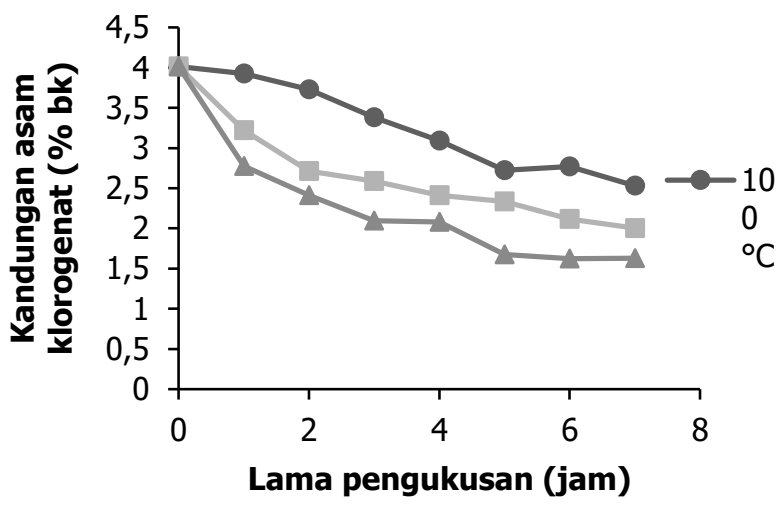

Gambar 6. Penurunan kandungan asam klorogenat biji kopi selama pengukusan

Dari Tabel 3 diketahui bahwa perubahan asam klorogenat biji kopi kukus mengikuti reaksi orde dengan nilai $\mathrm{R}^{2}$ mendekati 1 .

Pada Tabel 3 tampak bahwa persamaan orde reaksi dan nilai $R^{2}$ semakin berkurang dengan adanya peningkatan suhu. Pada suhu yang lebih tinggi, panas dan tekanan yang dihasilkan juga lebih tinggi sehingga laju penurunan asam klorogenat makin besar yang menyebabkan konstanta laju penurunan k makin tinggi seperti terlihat pada Tabel 4.

Tabel 4. Parameter Arrhenius perubahan asam klorogenat

\begin{tabular}{cccc}
\hline \multicolumn{2}{c}{ Suhu ( $\left.{ }^{\circ} \mathrm{K}\right)$} & \multicolumn{2}{c}{ Persamaan matematis } \\
\hline $\mathrm{T}$ & $1 / \mathrm{T}$ & $\mathrm{k}$ & $\ln \mathrm{k}$ \\
\hline 373 & 0,002681 & 0,071 & $-2,64508$ \\
383 & $0,002,11$ & 0,089 & $-2,41912$ \\
393 & 0,002545 & 0,12 & $-2,12026$ \\
\hline
\end{tabular}

Dengan memplotkan antara In $\mathrm{k}$ dan $1 / \mathrm{T}\left({ }^{\circ} \mathrm{K}\right)$, energi aktivasi (Ea) perubahan asam klorogenat biji kopi kukus dapat diketahui seperti pada Gambar 7.

Hasil analisis regresi linier dari plot $1 / \mathrm{T}$ dan In $\mathrm{k}$ pada penurunan asam klorogenat (Gambar 7) diperoleh persamaan $\mathrm{y}=-3841,1 \mathrm{x}+7,638$. Angka 3841,1 merupakan nilai Ea/R, dan $\mathrm{R}$ adalah konstanta gas $=8,314 \mathrm{~kJ} / \mathrm{molK}$. Nilai energi aktivasi (Ea) dapat diketahui $=3841,1 \times 8,314 \mathrm{~kJ} / \mathrm{molK}=31.934,91$ $\mathrm{kJ} / \mathrm{molK}$ yang merupakan besarnya energi minimal yang dibutuhkan molekul dalam biji kopi untuk menurunkan asam klorogenat. Nilai $\mathrm{k}$ dan Ea kafein dan asam klorogenat disajikan pada Tabel 5. 


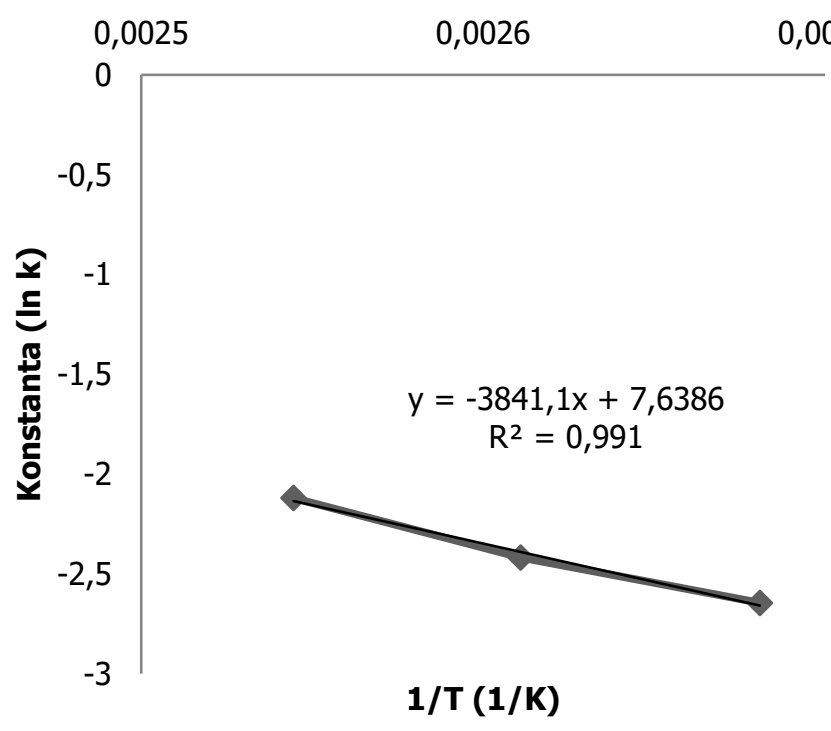

Gambar 7. Plot Arrhenius perubahan asam klorogenat

Tabel 5. Nilai k dan energi aktivasi kafein dan asam klorogenat

\begin{tabular}{|c|c|c|c|c|}
\hline \multirow{2}{*}{ Parameter } & \multicolumn{3}{|c|}{ Konstanta laju reaksi (k) } & \multirow{2}{*}{$\begin{array}{l}\text { Energi } \\
\text { aktivasi } \\
(\mathrm{kJ} / \mathrm{molK})\end{array}$} \\
\hline & $100^{\circ} \mathrm{C}$ & $110^{\circ} \mathrm{C}$ & $120^{\circ} \mathrm{C}$ & \\
\hline \multirow{2}{*}{$\begin{array}{l}\text { Kafein } \\
\text { Asam } \\
\text { klorogenat }\end{array}$} & 0,019 & 0,023 & 0,033 & $33.543,66$ \\
\hline & 0,071 & 0,089 & 0,12 & $31.934,91$ \\
\hline
\end{tabular}

Tabel 5 menunjukkan nilai konstanta laju reaksi (k) asam korogenat lebih besar dibandingkan nilai $\mathrm{k}$ kafein pada ketiga suhu yang diuji, walaupun energi aktivasi asam klorogenat sedikit lebih rendah dibandingkan kafein.. Hasil yang sama didapatkan oleh (JeszkaSkowron, Sentkowska, Pyrzyńska, \& De Peña, 2016), pengukusan biji kopi Robusta Indonesia dengan air panas $94^{\circ} \mathrm{C}$ mendapatkan penurunan asam klorogenat yang signifikan. Selanjutnya (Liang, Xue, Kennepohl, \& Kitts, 2016), menyatakan bahwa asam klorogenat dan isomernya mudah terurai menjadi senyawa radikal bebas lain bila diolah dengan suhu tinggi termasuk penyangraian. Hal ini menunjukkan bahwa asam klorogenat lebih rentan terhadap suhu tinggi dibandingkan kafein, sehingga menyebabkan energi aktivasi yang dibutuhkan lebih kecil dibandingkan energi aktivasi kafein.

Untuk menguji persamaan pada Tabel 3 (orde 1), perlu dilakukan validasi dengan menghitung kandungan asam klorogenat prediksi dengan rumus: $y=\exp (a . t+$ b) yang diperoleh dari Tabel 3. Hubungan kandungan asam klorogenat observasi dan prediksi untuk masingmasing suhu ditampilkan berturut-turut pada Gambar 8, 9, dan Gambar 10.

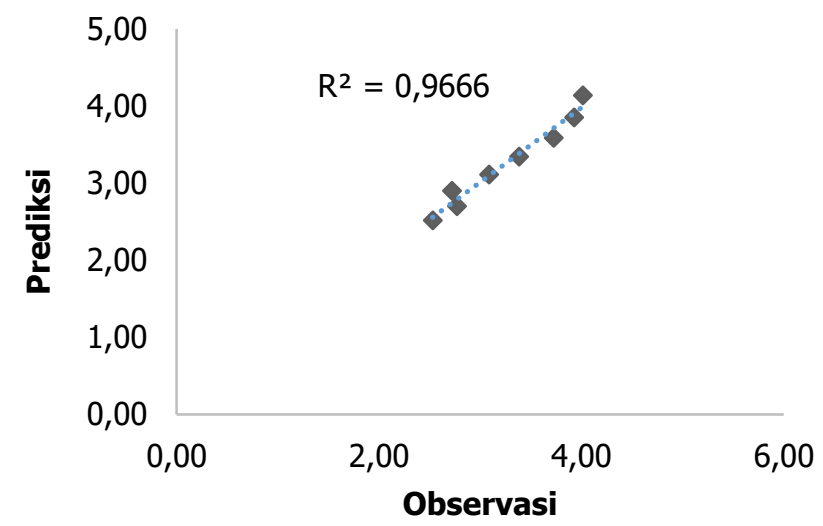

Gambar 8. Hubungan kandungan asam klorogenat (\%) prediksi dan observasi pada suhu $100^{\circ} \mathrm{C}$

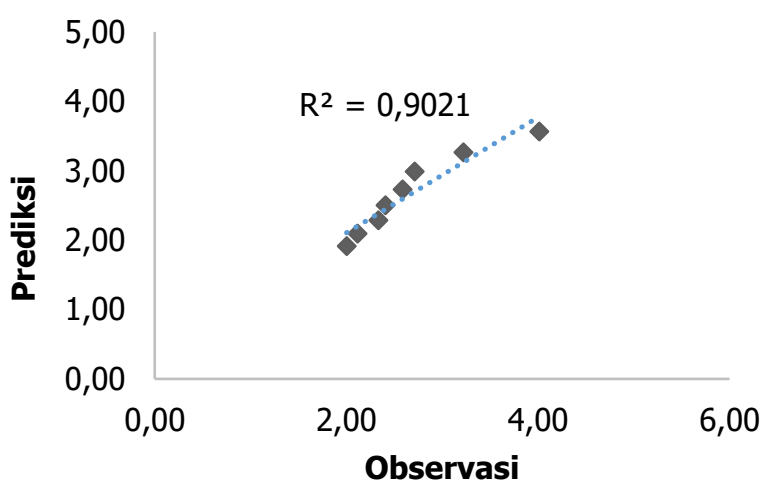

Gambar 9. Hubungan kandungan asam klorogenat (\%) prediksi dan observasi pada suhu $110^{\circ} \mathrm{C}$

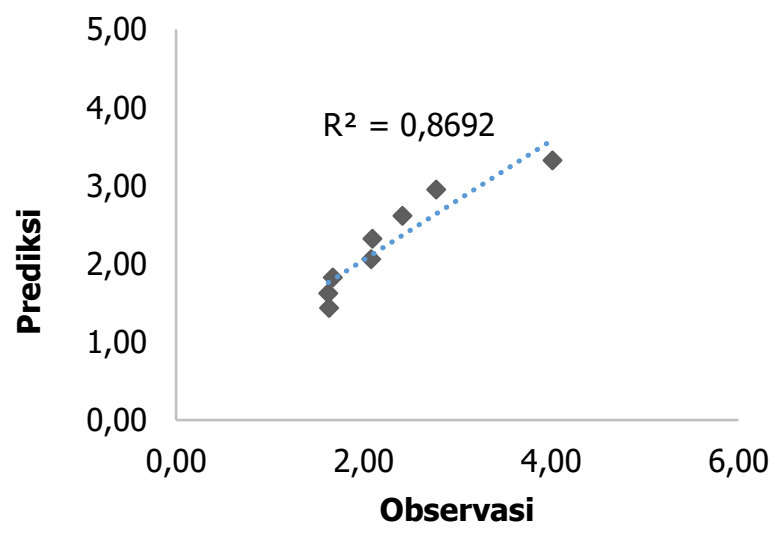

Gambar 10. Hubungan kandungan asam klorogenat (\%) prediksi dan observasi pada suhu $120^{\circ} \mathrm{C}$

Berdasarkan Gambar 8, 9, dan 10, nilai koefisien determinasi pada suhu 100,110 , dan $120{ }^{\circ} \mathrm{C}$ nilainya masing-masing 0,966; 0,902, dan 0,869. Dapat disimpulkan bahwa besarnya kandungan asam klorogenat prediksi mendekati nilai asam klorogenat observasi. 


\section{KESIMPULAN}

Pengukusan sistem tertutup selama 7 jam, berturutturut pada suhu 100,110 , dan $120{ }^{\circ} \mathrm{C}$ menurunkan kandungan kafein sebesar 13\%, 18\%, dan 25\% dan menurunkan kandungan asam klorogenat 37\%, 50\%, dan 59\%. Penurunan kafein mengikuti persamaan reaksi orde satu yaitu $y=-0,019 x+0,862$ pada suhu $100{ }^{\circ} \mathrm{C}$, $\mathrm{y}=-0,023 \mathrm{x}+0,820$ pada suhu $110{ }^{\circ} \mathrm{C}$, dan $\mathrm{y}=-$ $0,033 x+0,759$ pada suhu $120{ }^{\circ} \mathrm{C}$. Penurunan asam klorogenat mengikuti persamaan reaksi orde satu yaitu y $=-0,071 \mathrm{x}+1,421$ pada suhu $100{ }^{\circ} \mathrm{C}, \mathrm{y}=-0,089 \mathrm{x}+$ 1,271 pada suhu $110^{\circ} \mathrm{C}$, dan $\mathrm{y}=-0,120 \mathrm{x}+1,201$ pada suhu $120^{\circ} \mathrm{C}$. Besarnya energi aktivasi penuruan kafein biji kopi adalah 33.543,66 kJ/molK dan energi aktivasi untuk penuruan asam klorogenat biji kopi adalah 31.934,91 kJ/molK.

\section{DAFTAR PUSTAKA}

Almada, D. P. (2009). Pengaruh perubahan proses dekafeinasi kopi dalam reaktor kolom tunggal terhadap mutu kopi. Institut Pertanian Bogor.

BSN. (2004). Standar mutu kopi bubuk, Pub. L. No. ICS 67 140.20, p8-10. Indonesia.

Clarke, R.J. \& Macrae, R. (1987). Coffee. In Vol.2 (Technology). London: Elsivier Applied Science Publishers.

Clifford, M. N., \& Jarvis, T. (1988). The chlorogenic acids content of green robusta coffee beans as a possible index of geographic origin. Food Chemistry, 29(4), 291-298.

Clifford, M. N. (1985). Chemical and Physical Aspects of green coffee and coffee products. In Boteny, Biochemistry, and Production of Bean \& Beverage (pp. 305-374). Westport, Connecticut: The AVI Publ.Co.Inc.

Cropley, V., Croft, R., Silber, B., Neale, C., Scholey, A., Stough, C., \& Schmitt, J. (2012). Does coffee enriched with chlorogenic acids improve mood and cognition after acute administration in healthy elderly? A pilot study. Psychopharmacology, 219(3), 737-749. https://doi.org/10.1007/s00213-011-2395-0.

Jeszka-Skowron, M., Sentkowska, A., Pyrzyńska, K., \& De Peña, M. P. (2016). Chlorogenic acids, caffeine content and antioxidant properties of green coffee extracts: influence of green coffee bean preparation. European Food Research and Technology, 242(8), 1403-1409. https://doi.org/10.1007/s00217-016-2643-y.

Lara, D. R. (2010). Caffeine, mental health, and psychiatric disorders. Journal of Alzheimer's Disease, 20(SUPPL.1). https://doi.org/10.3233/JAD-2010-1378.

Lelyana, R. (2008). Pengaruh kopi terhadap kadar asam urata darah. Universitas Diponegoro. Semarang.

Liang, N., Xue, W., Kennepohl, P., \& Kitts, D. D. (2016). Interactions between major chlorogenic acid isomers and chemical changes in coffee brew that affect antioxidant activities. Food Chemistry, 213, 251-259. https://doi.org/10.1016/j.foodchem.2016.06.041.

Mubarak, A., Bondonno, C. P., Liu, A. H., Considine, M. J., Rich, L., Mas, E., ... Hodgson, J. M. (2012). Acute effects of chlorogenic acid on nitric oxide status, endothelial function, and blood pressure in healthy volunteers: A randomized trial. Journal of Agricultural and Food Chemistry, 60(36), 9130-9136. https://doi.org/10.1021/jf303440j.

Panggabean, E. (2011). Buku Pintar Kopi. Jakarta: PT. AgroMedia Pustaka.

Renate, D., Pratama, F., Yuliati, K., \& Priyanto, G. (2014).
Model Kinetika Degradasi Capsaicin Cabai Merah Giling Pada Berbagai Kondisi Suhu Penyimpanan. Agritech, 34(3), 330-336. Retrieved from https://journal.ugm.ac.id/agritech/article/view/9462/7036.

Sivetz, M. \& Desroiser, N. W. (1979). Coffee Technology. Westport, Connecticut: The AVI Publisher Co.Inc.

Tamakoshi, A., Lin, Y., Kawado, M., Yagyu, K., Kikuchi, S., \& Iso, H. (2011). Effect of coffee consumption on all-cause and total cancer mortality: Findings from the JACC study. European Journal of Epidemiology, 26(4), 285-293. https://doi.org/10.1007/s10654-011-9548-7.

Tripathi, H., Koshy, R., Kachroo, M., \& Mayachari, A. S. (2014). Method development and validation for quantification of chlorogenic acid in Coffea arabica extract using high performance liquid chromatography, 6(6), 8992.

Van Dijk, A. E., Olthof, M. R., Meeuse, J. C., Seebus, E., Heine, R. J., \& Van Dam, R. M. (2009). Acute effects of decaffeinated coffee and the major coffee components chlorogenic acid and trigonelline on glucose tolerance. Diabetes Care, 32(6), 1023-1025. https://doi.org/10.2337/dc09-0207.

Widyotomo, S., Purwadaria, H.K., \& Ismayadi, C. (2012). Peningkatan mutu dan nilai tambah kopi melalui pengembangan proses fermentasi dan dekafeinasi. In Prosiding InSINas (pp. 135-139).

Widyotomo, S. (2012). Optimasi suhu dan konsentrasi pelarut dalam dekafeinasi biji kopi menggunakan Response Surface Methodology Optimizing of temperature and concentration of solvent for coffee decaffeination using Response Surface Methodology, 28(3), 184-200.

Wijaya, D. A., \& Yuwono, S. S. (2015). PENGARUH LAMA PENGUKUSAN DAN KONSENTRASI ETIL ASETAT TERHADAP KARAKTERISTIK KOPI PADA PROSES DEKAFEINASI KOPI ROBUSTA Effect of Steaming Time and Ethyl Acetate Concentration against Characteristics of Coffee In Process Robusta Coffee Decaffeination, Jurnal Pangan dan Agroindustri 3(4), 1560-1566. 